\title{
Assessment of Building Collapse in Lagos Island, Nigeria
}

ADETUNJI, Michael, A; OYELEYE, Oyewale I and Akindele, O.A

Department of Urban and Regional Planning, Faculty of Environmental Sciences Ladoke Akintola University of Technology, PMB 4000, Ogbomoso, Oyo State Nigeria

\section{ABSTRACT}

Building collapse in Nigeria has become a serious problem that requires urgent address from all stakeholders in the building industry and government. Several lives and properties have been claimed by this ugly incidence across many urban centres in Nigeria. Unfortunately, man has been largely blamed to be responsible for almost all the incidences of building collapse due to human errors. Over 400 lives have been claimed in Lagos in the last 5 decades due to building collapse. No doubt, building collapse has gained a lot of research attention from the professionals in the building industry with the intention of finding lasting solutions to the ugly menace of building collapse in the country. Thus, this study makes use of both primary and secondary data with an intention to contribute its quota to the existing literature on measures to curb building collapse in Lagos Nigeria and beyond.

Keywords: Building Collapse, Building Industry, Professionals, Lives, Lagos, Nigeria

\section{INTRODUCTION}

It is saddened to note that safety of lives and properties are under serious threats as many urban centres in Nigeria continue to record different cases of building collapse in the recent time. This unfortunate experience has continued to gain research attention from all stakeholders in the built environment in order to examine the causes and fashion out measures to curb the incessant collapse of buildings especially at urban centres in Nigeria. Almost all the major cities (Abuja, Lagos, Ibadan, Port Harcourt, and Kano among others) in Nigeria have been hit with building collapse with unfortunate loss of many lives and properties. The first building collapse in Lagos was recorded in 1978 (Oni, 2010). On the $28^{\text {th }}$ of April 2010, a two-storey market plaza in Oshodi-Lagos, collapsed, killing at least four persons and leaving many others wounded; while over 400 lives have been lost in Lagos in the last five decades due to building collapse. Lagos Island has been an area that is more susceptible to building collapse in comparison with other part in Lagos State. This is in consensus with the opinion of Oni (2010) that many of the buildings collapsed in Lagos were concentrated around swampy terrain not far from the Lagos Lagoon, where land was reclaimed for building purposes many years ago without strict planning approval process.

From the opinions of Ayodeji (2011) and Adedeji (2013), building collapse is a state of complete failure when the structure has given way and most members caved-in or buckled. Fagbenle and Olawunmi (2010) see failure in building as the inability of the building components not being adequate to perform what are normally expected or required of those components. On the other hand, when part or whole structure has failed and suddenly gave way in a way that as a result of this failure, the building could not meet the purpose for which it was intended, the building has collapsed (Fagbenle and Olawunmi, 2010). Also, Olagunju et al. (2013) aver that building collapse is a total or partial failure of one or more components of a building leading to the inability of a building to perform its principal function of stability, safety and comfort. In line with these, building collapse can affect the totality of the 
DOI : https://dx.doi.org/10.26808/rs.aj.i7v1.04

American Journal of Sustainable Cities and Society

Issue 7, Vol. 1 January- December 2018

Available online on http://www.rspublication.com/ajscs/ajsas.html

ISSN $2319-7277$

building or can partially affect some parts of the building and in this regard, safety and stability must be of utmost concern (Ayeni and Adedeji, 2015).

According to Wardhana and Hadipriono (2003), collapse and distress are subsets of failure in a building. In terms of functionality, collapse occurs when the entire or a substantial part of a structure comes down thereby losing the ability to perform its function. Distress is the un-serviceability of a structure or its components that may or may not result in a collapse, and refers to a particular condition of the structure which has undergone some deformations without losing the whole structural integration (Oni, 2010). Building collapse may be classified as total and partial collapses (Oni, 2010). Total collapse implies that several primary structural members of a building have fallen down completely while partial collapse suggests a condition where only some of the primary structural members of the building components have fallen down (Oni, 2010).

Several factors have been linked to the causes of building collapse in the literature which can be broadly grouped into two which are natural and human error. The causes include these among others; faults from all professionals in the built environment (Ayininuola and Olalusi, 2004); lack of soil investigation before construction (Oloyede et al., 2010); natural occurrence such as flood, tornadoes and earthquakes among others (Madu, 2005); inexperience or poor supervision (Fagbenle and Olawunmi, 2010); deficiencies in drawings and execution (Ayeni and Adedeji, 2015); inability of client to pay for quality services by engaging right and/or experienced professionals (Adebayo, 2000); overturning of structures due to heavy wind loads, sliding of structures due to high wind, roof uplift or sliding, and building sway due to lateral loads (Merritt and Ambrose, 1989); proliferation of substandard building materials in the country and also failure or ineffectiveness of the provisions of laws or regulations regulating construction exercise from the concerned professionals like Town Planners, Builders, Architects, Engineers and Surveyors. This study thus assesses the causes of building collapse in Lagos Island and fashion out measures to mitigate further collapse of building in Lagos State and beyond.

\section{STUDY AREA}

Lagos is about $6.5^{\circ}$ North of the equator and $3.5^{\circ}$ East of the Greenwich Meridian. The state is located on the South Western part of Nigeria on the narrow coastal plain of the Bright of Benin. It lies approximately on longitude $2^{\circ} 42^{`} \mathrm{E}$ and $3^{0} 22^{`} \mathrm{E}$ respectively and between Latitude $6^{0} 22^{\circ} \mathrm{N}$ and $6^{0} 42 \mathrm{~N}$. It is bounded in the North and East by Ogun State in Nigeria, in the West by the Republic of Benin, and stretches over 180 kilometers along the Guinea coast of the Bright of Benin on the Atlantic Ocean. Its jurisdiction comprises the city of Lagos and four administrative divisions of Ikeja, Ikorodu, Epe and Badagry. Politically, Lagos State encompasses an area of 358,862 hectares or 3,577sq.km. Lagos State is the former capital city of Nigeria replaced by Abuja on 12th December, 1991 but remains the commercial centre of Nigeria (Oni, 2010). In 1995, Lagos had experienced over 100\% increase in the population size from the population the city at independence of Nigeria (Oyeleye, 2013), which made Lagos to be the fifteenth largest city in the world. By 2015, it was predicted by the United Nations (1995) that Lagos in Nigeria would have been the third largest city in the world with population of about 24.4 million. With the continuous influx of people from every part of the country and beyond to Lagos State due to the presence of diverse economic opportunities, there has been unavoidable pressure on construction of commercial, relaxation and religious centres, residential developments and construction projects for other demanding land uses to meet up with the housing needs of increasing population. Thus, challenges on the standard of constructions in Lagos due to increasing high demand have become serious concerns. 


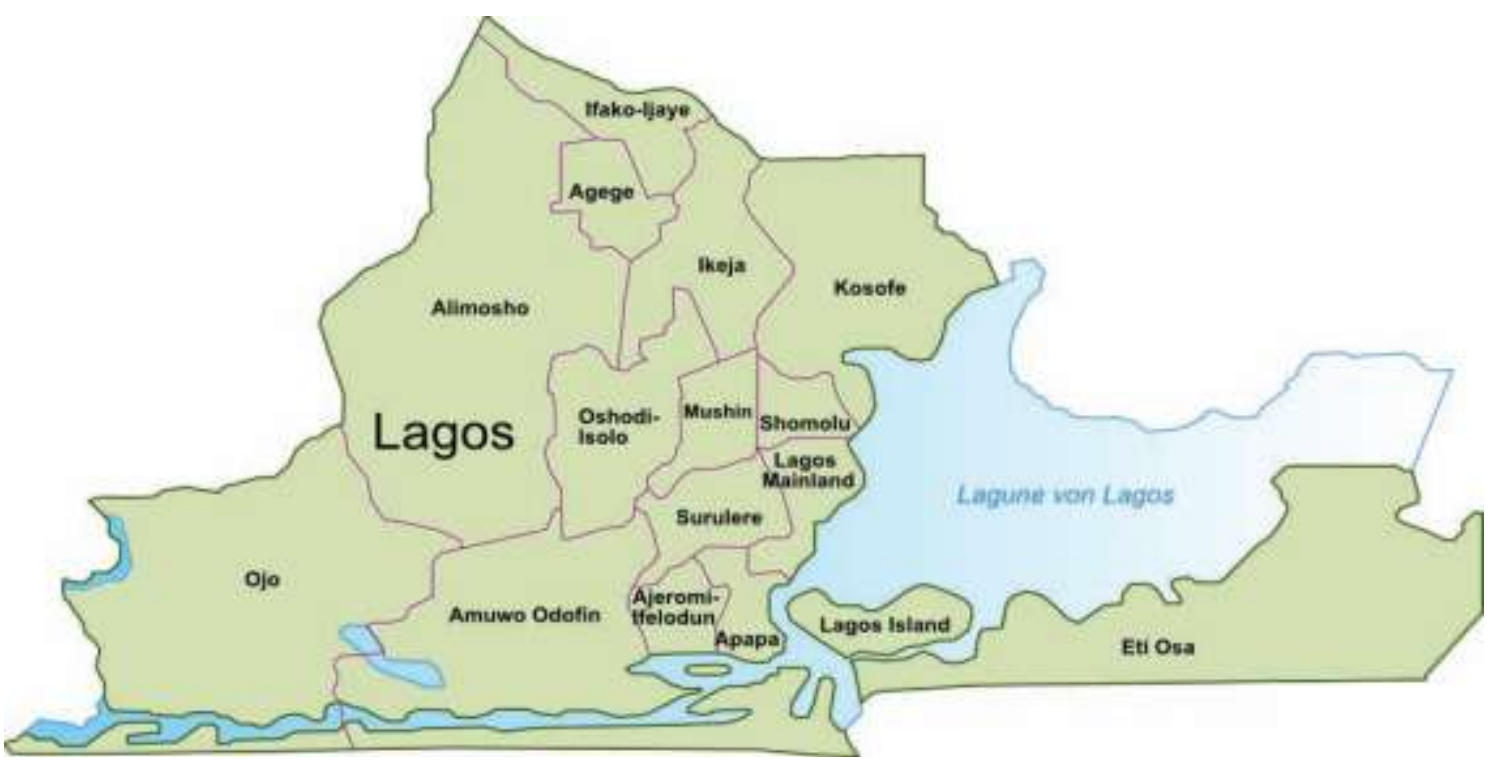

Figure 1.1: Map of Lagos Metropolis showing the Local Government Areas Source: Adapted from Oni, 2010.

\section{METHODOLOGY}

This study relies on both primary and secondary data. The sampling frame is Lagos Island Local Government of Lagos State Nigeria. This comprises eleven (11) salient localities which form the sampling basis for this study. For the purpose of adequate representation, six (6) out of eleven (11) localities were sampled using ballot system. This was done using the lucky dip method where all the areas represented by number one (1) to eleven (11) were pooled together. Though, all the eleven (11) had equal chances to be picked, but the first six (6) localities represented in Table 3.1 were eventually picked for the study. Information obtained from LASBCA revealed the area where building had collapsed in the sampled localities between 2011 and 2015. The sites of building collapses in the 6 localities of the study were sampled purposively and questionnaires were administered to two hundred and forty (240) respondents across the six sampled localities as presented in Table 3.1. In each of the zones, the first building from which respondent was drawn was sampled randomly while the rest were chosen at interval of every five buildings.

\section{Table 3.1: Sampling Frame and Size}

\begin{tabular}{|l|l|c|c|c|c|}
\hline S/N & Localities & $\begin{array}{c}\text { Sampled } \\
\text { localities }\end{array}$ & $\begin{array}{c}\text { No of Collapsed } \\
\text { Building (2011-2015) }\end{array}$ & $\begin{array}{c}\text { No of } \\
\text { Questionnaire }\end{array}$ & $\begin{array}{c}\text { Percentage } \\
\text { \% }\end{array}$ \\
\hline 1 & Epetedo & $*$ & 1 & 16 & 6.6 \\
\hline 2 & Idumota & $*$ & 3 & 48 & 20 \\
\hline 3 & Isale Eko & $*$ & 5 & 80 & 33.3 \\
\hline 4 & Oke popo & $*$ & 3 & 48 & 20 \\
\hline 5 & Isalegangan & $*$ & 2 & 32 & 13.3 \\
\hline 6 & Lafiaji & $*$ & 1 & 16 & 6.6 \\
\hline 7 & Araromi Odo & & 1 & 0 & 0 \\
\hline 8 & Popo Aguda & & 2 & 0 & 0 \\
\hline 9 & Agarawu & & 2 & 0 & 0 \\
\hline 10 & Offin & & 1 & 0 & 0 \\
\hline 11 & Olowogbowo & & 1 & 0 & 0 \\
\hline \multicolumn{2}{|l|}{ TOTAL $=$} & 22 & 240 & $100.0 \%$ \\
\hline
\end{tabular}

Source: Authors' Survey, 2015 


\section{FINDINGS OF THE STUDY}

\subsection{LAGOS STATE BUILDING CONTROL AGENCY (LASBCA)}

Lagos State Building Control Agency (LASBCA) is an arm of Lagos State Ministry of Physical Planning and Urban Development. The vision of Lagos State Building Control Agency is to ensure that building in Lagos State are designed, constructed and maintained to a very high standard of safety, avoiding loss of lives and properties through its building regulatory system. LASBCA came into existence in August 12, 2012 and it was empowered to carry out the following responsibilities (Lagos State Ministry of Physical Planning and Urban Development, 2016);

i. Enforcement of building Control Regulations

ii. Regulation and inspection of building works and certification of various stages of building construction as well as keeping of such records

iii. Removal of illegal and non-conforming buildings

iv. Identification and removal of distressed buildings to prevent collapse

v. Issuance of certificate of completion and fitness for habitation

vi. Administration of building control in all ramification

vii. Cooperation with the Lagos State Planning Permit Authority to achieve zero tolerance to illegal development and building collapse.

viii. Operational control of its local building control offices.

ix. Enforcing the provisions of the law and its regulation in respect of inspection of building verification and certification of building insurance as well as

x. Public enlightenment on building control.

Table 4.1: List of Collapsed Building from 2011-2015 in Lagos Island

\begin{tabular}{|c|c|c|c|c|}
\hline $\mathbf{S} / \mathbf{N}$ & LOCATION OF BUILDING & HEIGHT & $\begin{array}{l}\text { DATE OF } \\
\text { INCIDENCE }\end{array}$ & $\begin{array}{l}\text { REMARKS } \\
\text { (LIVES LOST) }\end{array}$ \\
\hline 1 & 6 Mogaji Street Idumota Lagos Island & 4 storey building & 13 march 2015 & $\begin{array}{l}\text { Total collapse/11 } \\
\text { dead }\end{array}$ \\
\hline 2 & No 34, Salami Street, Okepopo. Lagos & 3 storey building & 19 July, 2013 & Partial collapse \\
\hline 3 & 13 Thomas str. Off Adeniji, Isale-Eko & 4 storey building & May, 2011 & Partial collapse \\
\hline 4 & Shagamu Oroyinyin Lagos Island & 4 storey building & 25 August,2013 & Partial collapse \\
\hline 5 & John Street Idumota Lagos Island & 4 storey building & 6 July, 2014 & Total collapse \\
\hline 6 & Saliu ARiyo street, Lafiaji. Lagos & 3 storey building & 6 August, 2012 & Partial collapse \\
\hline 7 & 35b, Seriki Street, Isale-Eko & 4 storey building & 2014 & $\begin{array}{l}\text { Total collapse / } \\
12 \text { people were } \\
\text { injured, } 4 \text { dead }\end{array}$ \\
\hline 8 & 35, Swamp Street, Odunfa, Isale-Eko & building & $\begin{array}{ll}21 & \text { October, } \\
2015 & \end{array}$ & $\begin{array}{l}\text { Many people } \\
\text { were injured, } 1 \\
\text { dead }\end{array}$ \\
\hline 9 & 77 Aroloya Street, Epetedo, Lagos & y building & 2015 & Partially collapse \\
\hline 10 & 8, Okepopo Street, Lagos Island & 3 storey building & 2014 & Partially collapse \\
\hline 11 & Isalegangan, Lagos Island & 4 storey building & 15 May, 2013 & Total collapse \\
\hline 12 & Isalegangan, Lagos Island & 3 storey building & 21 March, 2015 & Total collapse \\
\hline 13 & Isale-Eko, Lagos Island & 4 storey building & 24 June, 2014 & Partially collapse \\
\hline 14 & Ikepopo, Lagos Island & 3 storey building & March, 2015 & Total collapse \\
\hline 15 & Idumota, Lagos Island & 4 storey building & May, 2015 & Total collapse \\
\hline
\end{tabular}

Source: Lagos State Building Control Agency (LASBCA) 2016. 
Though, the aim of Lagos State Building Control Agency is to achieve a zero percent of building collapse in Lagos State. However, from the data released by the same Agency in 2016 as presented in Table 4.1, within 4 years between 2011 and 2015, about 15 cases of building collapse were recorded in Lagos Island which is just one out of 11 localities in Lagos State with record of about 16 dead and several persons injured. Building collapse has become a serious problem in the study area. A clear observation from the record shows that all the buildings collapsed in Lagos Island in the aforementioned period were storey buildings. Thus, intensive use of land requires adequate attention from all stakeholders in the building industry in order to protect lives and properties in Lagos State

\subsection{TYPES OF BUILDING IN THE STUDY AREA}

Table 4.2 shows the types of building that exists in the study area as given by the respondents; it is revealed by Table 4.2 that $96.3 \%, 1.7 \%$ and $1.2 \%$ of respondents reported the existence of storey building, Brazilian type (face to face) and self-contain bungalow in the study area respectively, while $0.8 \%$ of respondents identified duplex building in the study area. Meanwhile, it is of high interest to report here that storey building is the most common types of building in the study area according to the majority of the respondents due to lack of land availability in Lagos Island and as such metamorphosis of bungalows into storey building are seriously embraced. This shows that intensive use of land is given higher priority with high-rise structures as against extensive use of land. With increasing level of high-rise construction in the study area, it has become paramount for highly professionals in the built environment to be engaged by the developers to execute such projects in order to forestall incessant collapse.

Table 4.2: Types of building in the study area

\begin{tabular}{|l|l|l|}
\hline Type of Building & Frequency & Percentage (\%) \\
\hline Face to face & 4 & 1.7 \\
\hline Storey building & 231 & 96.3 \\
\hline Self-contain bungalow & 3 & 1.2 \\
\hline Duplex & 2 & 0.8 \\
\hline Total & 240 & 100 \\
\hline
\end{tabular}

Source: Authors' Survey, 2015

\subsection{USE OF BUILDING IN THE STUDY AREA}

The use of building as reported by the respondents in the study area is presented in Table 4.3. According to the Table, 5.4\% of buildings were fully used for residential purposes, while $22.9 \%$ and $71.7 \%$ of the buildings in the study area were commercial and mixed uses respectively. It could be observed in the table that most of the building uses in the study area are mixed uses according to the information given by the majority of respondents in the study area. This shows that most of the buildings in the study area are used for mixed purposes which must have been conversion from one use e.g residential to multipurpose uses which the buildings are not designed to serve such multiple purposes. This creates more pressure sometimes on such buildings and could as well result to collapse. It has been observed that Planning approvals are not sought for most buildings used for mixed uses.

Table 4.3: Use of Building in the Study Area

\begin{tabular}{|l|l|l|}
\hline Use of Building & Frequency & Percentage (\%) \\
\hline Fully residential & 13 & 5.4 \\
\hline Commercial & 55 & 22.9 \\
\hline Mixed uses & 172 & 71.7 \\
\hline Total & 240 & 100 \\
\hline
\end{tabular}

Source: Authors' Survey, 2015 


\subsection{STAGES AT WHICH BUILDINGS COLLAPSE IN THE STUDY AREA}

It is evident from Table 4.4 that most buildings in the study area that experience collapse are fully completed and mostly habited. Table 4.4 shows that only buildings under construction in Lafiaji in the study area are opined by the respondents to experience collapse with about $68.8 \%$ as against completed buildings. This shows that lives and properties at risks during building collapse are generally higher in the study area as most building collapsed are completed and likely habited as against building under construction.

Table 4.4: Stages at which Buildings Collapse in the Study area

\begin{tabular}{|l|l|l|l|l|l|l|}
\hline \multirow{2}{*}{ Area } & \multicolumn{6}{|c|}{ Building collapse } \\
\cline { 2 - 7 } & Under construction & Completed & \multicolumn{2}{l|}{ No response } \\
\cline { 2 - 7 } & $\mathbf{F}$ & $\mathbf{\%}$ & $\mathbf{F}$ & $\mathbf{\%}$ & $\mathbf{F}$ & \% \\
\hline Epetedo & 4 & 25.0 & 12 & 75.0 & 0 & 0.0 \\
\hline Idumota & 12 & 25.0 & 35 & 72.9 & 1 & 2.1 \\
\hline Isale-Eko & 5 & 6.3 & 71 & 88.8 & 4 & 5.0 \\
\hline Okepopo & 10 & 20.8 & 37 & 77.1 & 1 & 2.1 \\
\hline Isalegangan & 8 & 25.0 & 22 & 68.8 & 2 & 6.3 \\
\hline Lafiaji & 11 & 68.8 & 3 & 18.8 & 2 & 12.5 \\
\hline Total & 50 & 20.8 & 180 & 75.0 & 10 & 4.2 \\
\hline
\end{tabular}

Source: Authors' Survey, 2015

\subsection{ANNUAL INCIDENCE OF BUILDING COLLAPSE IN THE STUDY AREA}

Resident of Idumota, Isale-Eko, Okepopo and Isalegangan were observed to be experiencing building collapse at least twice a year. The attestation of $66.7 \%$ respondents affirms this. Epetedo and Lafiaji among the sampled areas experience building collapse once in a year. This implies that, in Lagos Island, more areas do experience high incidence of building collapse (At least twice a year) residents of Idumota, Isale-Eko, Okepopo and Isalegangan probably experience incidence of building collapse at a higher frequency as a result of incompliance of residents with the planning codes and standards and construction of tall buildings in a water lodged area.

Table 4.5: Annual Incidence of Building Collapse

\begin{tabular}{|c|c|c|c|c|c|c|c|c|c|c|}
\hline \multirow{3}{*}{ Area } & \multicolumn{8}{|c|}{ Level of occurrence } & \multirow{2}{*}{\multicolumn{2}{|c|}{$\begin{array}{l}\text { Total of } \\
\text { questionnaires }\end{array}$}} \\
\hline & \multicolumn{2}{|c|}{ Once } & \multicolumn{2}{|c|}{ Twice } & \multicolumn{2}{|c|}{$\begin{array}{l}\text { More than } \\
\text { twice }\end{array}$} & \multicolumn{2}{|c|}{ No response } & & \\
\hline & $\mathrm{F}$ & $\%$ & $\mathrm{~F}$ & $\%$ & $\mathrm{~F}$ & $\%$ & $\mathrm{~F}$ & $\%$ & $\mathrm{~F}$ & $\%$ \\
\hline Epetedo & 10 & 62.5 & 1 & 6.3 & 5 & 31.3 & 0 & 0.0 & 16 & 6.7 \\
\hline Idumota & 5 & 10.4 & 32 & 66.7 & 11 & 22.9 & 0 & 0.0 & 48 & 2.0 \\
\hline Isale-Eko & 1 & 1.25 & 49 & 61.3 & 29 & 36.3 & 1 & 1.3 & 80 & 33.3 \\
\hline Okepopo & 19 & 39.6 & 24 & 50.0 & 4 & 8.3 & 1 & 2.1 & 48 & 20.0 \\
\hline Isalegangan & 3 & 9.4 & 18 & 56.3 & 11 & 22.9 & 0 & 0.0 & 32 & 13.3 \\
\hline Lafiaji & 7 & 43.8 & 3 & 18.8 & 5 & 31.3 & 1 & 6.3 & 16 & 6.7 \\
\hline Total & 35 & 18.8 & 127 & 52.9 & 65 & 27.0 & 3 & 1.3 & 240 & 100 \\
\hline
\end{tabular}

Source: Authors' Survey, 2015

\subsection{CAUSES OF BUILDING COLLAPSE IN LAGOS ISLAND}

This section is concerned with identification of the actual causes of building collapse in the study area. Some of the causes of building collapse are connected with the competence of professionals in the construction of building: Architects (design), Civil Engineer 
DOI : https://dx.doi.org/10.26808/rs.aj.i7v1.04

American Journal of Sustainable Cities and Society

Issue 7, Vol. 1 January- December 2018

Available online on http://www.rspublication.com/ajscs/ajsas.html

ISSN $2319-7277$

(construction) and Quantity Surveyor (Costing) among others. Many respondents also hold opinion that Town Planning has not been effective in the area of monitoring and in some cases granting approvals to designs with structural deficiencies in terms of professional specifications.

Table 4.6: Causes of Building Collapse

\begin{tabular}{|c|c|c|c|c|c|c|c|c|c|c|c|}
\hline \multirow[t]{3}{*}{$\mathbf{S} / \mathbf{N}$} & \multirow{3}{*}{$\begin{array}{l}\text { CAUSES OF } \\
\text { BUILDING } \\
\text { COLLAPSE }\end{array}$} & \multicolumn{5}{|c|}{ RATING } & \multirow{3}{*}{ TOTAL } & \multirow{3}{*}{ SWV } & \multirow{3}{*}{$\mathrm{CBC}$} & \multirow{3}{*}{$(\mathbf{X}-\mathbf{X})$} & \multirow{3}{*}{$(\mathbf{X}-\bar{X})^{2}$} \\
\hline & & SA & $\overline{\mathbf{A}}$ & PA & D & SD & & & & & \\
\hline & & 5 & 4 & 3 & 2 & 1 & & & & & \\
\hline 1 & $\begin{array}{l}\text { Non consultation } \\
\text { of professionals }\end{array}$ & 1030 & 112 & 18 & 0 & 0 & 240 & 1160 & 4.83 & 0.71 & 0.49 \\
\hline 2 & $\begin{array}{l}\text { Poor/no } \\
\text { supervision by } \\
\text { contractors }\end{array}$ & 990 & 124 & 33 & 0 & 0 & & 1157 & 4.82 & 0.7 & 0.423 \\
\hline 3 & $\begin{array}{l}\text { Refusal } r \\
\text { approve } \text { building } \\
\text { plans }\end{array}$ & 940 & 140 & 51 & 0 & 0 & & 1131 & 4.71 & 0.59 & 0.348 \\
\hline 4 & $\begin{array}{l}\text { Alteration of } \\
\text { approve drawings }\end{array}$ & 875 & 120 & 81 & 16 & 0 & & 1092 & 4.55 & 0.43 & 0.185 \\
\hline 5 & $\begin{array}{ll}\text { Approval of } \\
\text { technically } \\
\text { deficient } \\
\text { drawings }\end{array}$ & 170 & 680 & 111 & 6 & 0 & & 947 & 3.95 & -0.17 & 0.029 \\
\hline 6 & $\begin{array}{l}\text { Illegal alteration } \\
\text { to } \quad \text { existing } \\
\text { buildings }\end{array}$ & 640 & 112 & 213 & 18 & 0 & & 983 & 4.10 & -0.02 & 0.0004 \\
\hline 7 & $\begin{array}{ll}\text { Poor/ } & \text { no } \\
\text { monitoring } & \text { by } \\
\text { town planners } & \end{array}$ & 260 & 600 & 81 & 22 & 0 & & 1045 & 4.35 & 0.23 & 0.053 \\
\hline 8 & $\begin{array}{l}\text { Economizing } \\
\text { building } \\
\text { materials }\end{array}$ & 590 & 172 & 81 & $\begin{array}{l}10 \\
4\end{array}$ & 0 & & 947 & 3.95 & -0.17 & 0.029 \\
\hline 9 & $\begin{array}{l}\text { Corruption of } \\
\text { artisans }\end{array}$ & 440 & 204 & 282 & 12 & 1 & & 939 & 3.91 & -0.21 & 0.044 \\
\hline 10 & $\begin{array}{l}\text { Use } \\
\text { substandard } \\
\text { building } \\
\text { materials }\end{array}$ & 230 & 384 & 237 & 51 & 7 & & 909 & 3.79 & -0.33 & 0.1089 \\
\hline 11 & $\begin{array}{l}\text { Inadequate } \\
\text { knowledge } \\
\text { builders }\end{array}$ & 575 & 224 & 156 & 6 & 14 & & 975 & 4.06 & -0.06 & 0.004 \\
\hline 12 & $\begin{array}{l}\text { Inefficient } \\
\text { workmanship/lab } \\
\text { our }\end{array}$ & 155 & 231 & 72 & 38 & 87 & & 583 & 2.43 & -1.69 & 2.856 \\
\hline 13 & $\begin{array}{l}\begin{array}{l}\text { Activities } \\
\text { quacks }\end{array} \\
\end{array}$ & 690 & 176 & 78 & 42 & 11 & & 997 & 4.15 & 0.03 & 0.0009 \\
\hline & Total & & & & & & & & 53.6 & Mean & 4.12 \\
\hline
\end{tabular}

Source: Authors' Survey, 2015

$\mathrm{CBC}=$ Causes of Building Collapse

$X=\Sigma C B C=\frac{53.6}{13}=4.12$
$X=\frac{\Sigma(X-X)^{2}}{N}=\frac{3.6582}{13}=0.2814$ 
Standard Deviation $($ S.D $)=\sqrt{ }$ Variance $=\sqrt{ } 0.2814=0.531$

Coefficient of Variation $=(\operatorname{SD} \times 100)=(0.531 \times 100)=53.1$

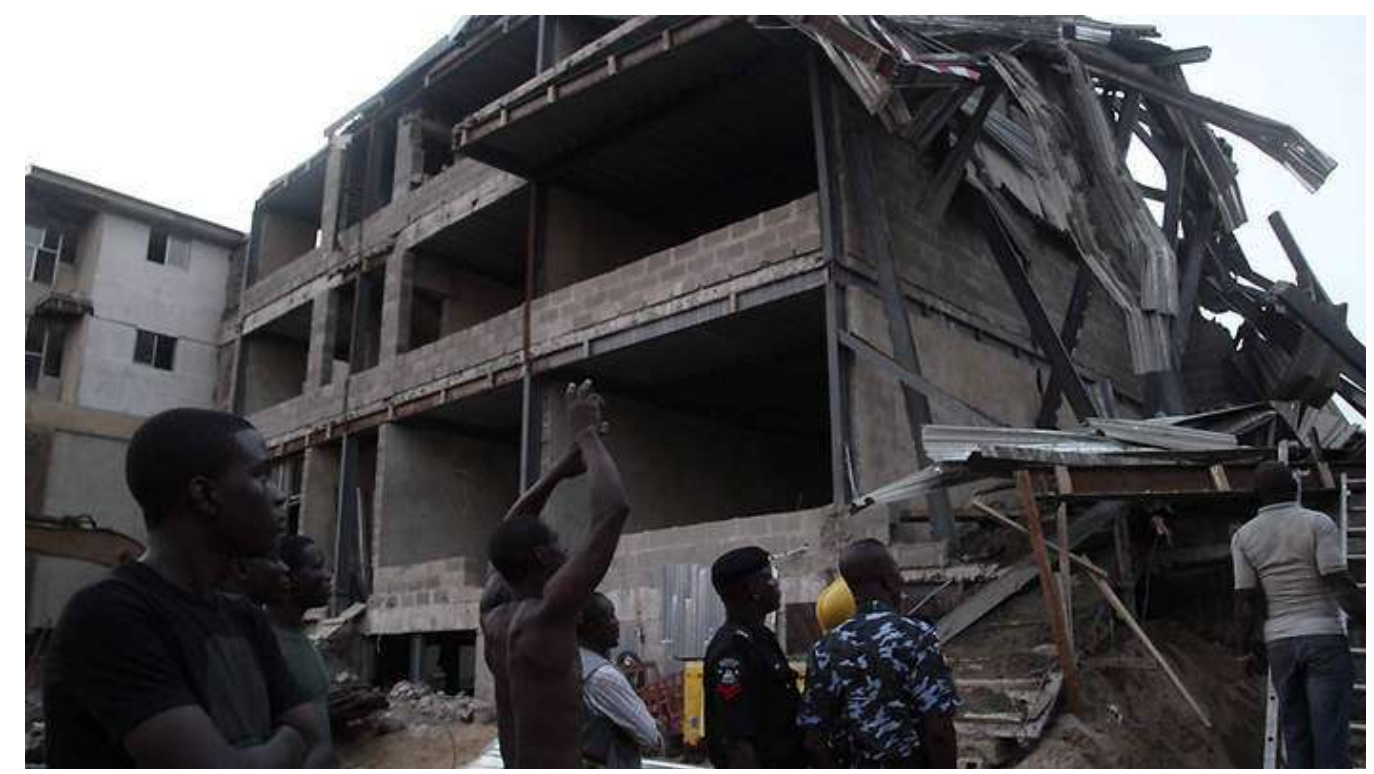

Figure 10: Collapse of Twin four Storey Building in Lagos

Source: http://www.sbs.com.au/news/article/2013/11/05/four-dead-nigeria-building-collapse Collapse of a twin four storey duplex shown in Figure 10 occurred on the 3rd of November, 2013 in Victoria Island leaving four dead and twenty-five injured; cause of collapse unknown. Adapted from Ayeni and Adedeji (2015)

\subsection{EFFECTIVENESS AND ENFORCEMENT OF PHYSICAL PLANNING REGULATION IN RELATION TO BUILDING DEVELOPMENT IN LAGOS ISLAND}

Under this subsection, attention is focused on the effectiveness of physical planning regulations in the study area. This is with an intention to strike a balance between the standard of building constructed in the study area and the incidence of building collapse in the study area. In addition to members of the public, the Town Planning Officers also served as the respondents in this regard, and five of them were interviewed. Table 4.7 shows that public awareness of Town Planning regulation on building development is very poor with just $2.1 \%$ of the respondents who claimed to be seriously aware of the regulation. Also, $41 \%$ of the respondents claimed not to be aware at all on the regulation of Town Planning on building development. This has revealed that developers or clients do not place priority on getting planning approval before embarking on their developments. However, about $54 \%$ of the respondents also claimed to be aware of the Town Planning regulations on building development.

Table 4.7: Public Awareness of Town Planning Regulation on Building Development

\begin{tabular}{|l|l|l|}
\hline Level of public awareness & \multicolumn{1}{|c|}{ Frequency } & Percentage (\%) \\
\hline Seriously aware & 5 & 2.1 \\
\hline Aware & 130 & 54.2 \\
\hline Not aware & 100 & 41.7 \\
\hline No response & 5 & 2.1 \\
\hline Total & 100 & 100 \\
\hline
\end{tabular}

Source: Authors' Survey, 2015 


\subsection{EFFECTIVENESS OF TOWN PLANNING REGULATION-ENFORCEMENT}

Concerning the effectiveness of Town Planning Regulation Enforcement in the study area, $45.5 \%$ of respondents as shown in table 4.6.2 noted it is not effective, while $47.1 \%$ and $7.5 \%$ gives the information that it is effective and very effective respectively. Only $0.8 \%$ or respondents refused to respond. However, it could be conveniently reported here that majority of respondents express the fact that town planning regulation enforcement is effective in the study area. With this one may be tempted to question that effectiveness of other allied professional involved in building construction in the study area.

Table 4.8: Effectiveness of Town Planning Regulation Enforcement

\begin{tabular}{|l|l|l|}
\hline $\begin{array}{c}\text { Effectiveness Regulation } \\
\text { Enforcement }\end{array}$ & \multicolumn{1}{c|}{ Frequency } & \multicolumn{1}{c|}{ Percentage (\%) } \\
\hline Not effective & 109 & 45.4 \\
\hline Effective & 113 & 47.1 \\
\hline Very effective & 18 & 7.5 \\
\hline No response & 2 & 0.8 \\
\hline Total & 100 & 100 \\
\hline
\end{tabular}

Source: Authors' Survey, 2015

\subsection{LEVEL OF BUILDING PLAN APPROVAL (2011-2015)}

It is observed from Table 4.9 shows that the number of building approval by the Town Planning Authority in the study area is declining significantly. This might not be unconnected with the fact that the land in the study area is gradually being exhaustive. Hardly can one see vacant land, and as reported above, most of the ownership of land in the study area is by leasehold. It can also be observed in the table that there is no building approval for industrial land and mixed land use in the study area, the reason being that Lagos Island is not an industrial base area. What is actually prominent in the area apart from residential use is commercial use where buying and selling of goods and services are the order of the day. It is not untrue to believe that some residences in the study area might have been converted to commercial uses and some subjected to mixed use without Town Planning Approval which must have contributed to increasing building collapse as such buildings now perform far above the purpose of the original design that they are meant for.

Table 4.9: Number of Approved Building Plan

\begin{tabular}{|c|c|c|c|c|c|}
\hline \multirow{2}{*}{$\begin{array}{c}\text { Land use } \\
\text { types }\end{array}$} & \multicolumn{5}{|c|}{ Number of approved building plan } \\
\hline & 2011 & 2012 & 2013 & 2014 & 2015 \\
\hline Residential & 39 & 16 & 10 & & 7 \\
\hline Commercial & 26 & 8 & 6 & & 5 \\
\hline Industrial & - & - & - & & - \\
\hline Public & 7 & - & - & & - \\
\hline Mixed & - & - & - & & - \\
\hline Total & 72 & 21 & 16 & & 12 \\
\hline
\end{tabular}

Source: Lagos Island Town Planning Authority, 2015

\section{CONCLUSION AND RECOMMENDATIONS}

There is no doubt that building collapse has claimed so many lives and properties in major cities in Nigeria. The pains of the loved ones loosed to building collapse remain with many people and such ugly occurrence has to be mitigated. It has been confirmed by several studies that mitigation of building collapse is possible as the unfortunate incidence of 
building collapse is largely man-made as against natural cause. That indicates everyone has roles to play in forestalling future collapse of buildings. Blames for the collapse are not only restricted to professionals involved in building industry like Architects, Engineers, Town Planners, Builders and Surveyors for deficiencies in their services, but all stakeholders and/or non-professionals concerned with the project. This study concludes by providing the following suggestions as measures to curb building collapse in Nigeria;

1. Nigeria Government has greatly failed in the area of having adequate members of staff who are professionals in agencies that are responsible for building control and approval across the three tiers of government. Nigeria government has to rise to the task of employing more professionals in the building industry in order to have concerted efforts in curbing building collapse.

2. Many professionals engaged by governments are totally with obsolete ideas and technical-know-how on designs and construction activities which play key roles in professional discharge of their duties. Continuous training and workshops have to be organized for government workers to keep them up-to-date on designs and construction activities.

3. Standard Organization of Nigeria (SON) has to promptly wake up to her duties of ensuring quality building materials are in the market for construction. SON needs to embark on effective monitoring with heavy sanctions meted out to violators of correct specifications in the production of materials used for construction.

4. No professional in the building industry should parade him/herself as a jack of all trades by dabbling into the duties of other allied professions without seeking or having adequate and necessary professional knowledge on such actions.

5. All professionals in the building industry should work together as a team and not as competitors or rivals. Unity among the professionals in building industry will play a key role in combatting building collapse.

6. Heavy sanctions should be meted out to developers who embark on construction without seeking for Planning Permit of such development. Similarly, adequate enlightenment programs on the importance of Physical Planning Regulations and building permit process in relation to development/construction should always be given priority by all the relevant professional bodies and government ministries or agencies that are responsible for physical planning.

7. Building plans submitted by any consultant or developer for Planning/Building Permit should be made to comply with New Building Code and other relevant provisions of laws guiding professional practices of those in building industry in Nigeria.

8. Professionals in the built environment should discharge their duties with high level of integrity in order to ensure that proper things are done in relation to designs, approval, execution and monitoring of projects.

9. Stiffer penalties supposed to be meted out to both the clients/developers and consultants that are connected to any collapsed building which claims lives.

10. Members of the community should be encouraged by the Ministry or government agencies responsible for Physical Planning to be doing whistle-blower approach by reporting any deficient building suspected to be a threat in the Community

\section{REFERENCES}

I. Adebayo, S.O (2000) "Improving Building Techniques "Proceedings of Workshops on Building Collapse: Causes, Prevention and Remedies. The Nigerian Institute of Builders, Lagos State 
II. Adedeji, J.A. (2013) "Environmental Disaster and Management: Case Study of Building Collapse in Nigeria" International Journal of Construction Engineering and Management, 2(3), 39-45

III. Ayeni, D.A and Adedeji, Y.M.D (2015) "Strategies for Mitigating Building Collapse in Nigeria: Roles of Architects and Other Stakeholders in the Building Industry" Civil and Environmental Research Vol.7, No.8

IV. Ayininuola, G.M. and Olalusi, O.O. (2004) "Assessment of Building failures in Nigeria: Lagos and Ibadan case study" African Journal of Science and Technology (AJST) Science and Engineering Series, 5(1), pp. 73-78

V. Ayininuola, G.M. and Olalusi, O.O. (2004) "Assessment of Building Failures in Nigeria: Lagos and Ibadan Case study" African Journal of Science and Technology (AJST) Science and Engineering series 5(1)

VI. Ayodeji, O. (2011) "An Examination of the Causes and Effects of Building Collapse in Nigeria" Journal of Design and Built Environment 9, 37-47

VII. Fagbenle, O.I and Olawunmi. A.O (2010) "Building Failure and Collapse in Nigeria: the Influence of the Informal Sector" Journal of Sustainable Development Vol. 3, No. 4

VIII. Lagos State Ministry of Physical Planning and Urban Development: Lagos State Building Control Agency (2016) "Duties and Responsibilities of LASBCA" Available at http://buildingcontrol.lagosstate.gov.ng/responsibilities/

IX. Madu, L.C (2005) "Journal of Nigeria Institute of Architects (N.I.A) Architecture: Research and Practice Vol. 1. No. 3

X. Merritt, F. and Ambrose, J. (1989) "Building Engineering and Systems Design" 2nd Edition. New York: Springer

XI. Olagunju, R.E, Aremu, S.C and Ogundele, J (2013) "Incessant Collapse of Buildings in Nigeria: An Architects View" Journal of Civil \& Environmental Research Vol.3 No 4

XII. Oloyode, S.A Omogun, C.B and Akinjare, O.A (2010) "Tracking Causes of Building Collapse in Nigeria" Journal of Sustainable Development Vol. 3. No. 3 PP. 127-132

XIII. Oni, A.O (2010) "Analysis of Incidences of Collapsed Buildings in Lagos Metropolis, Nigeria" International Journal of Strategic Property Management, 14:4, 332-346

XIV. Oyeleye, Oyewale I (2013) "Challenges of Urbanization and Urban Growth in Nigeria" American Journal of Sustainable Cities and Society Issue 2, Vol. 1, pp. 7995

XV. United Nations (1995) "World Urbanization Prospects: The 1994 Revision" New York.

XVI. Wardhana, K. and Hadipriono, F. C. (2003) Study of Recent Building Failures in the United States" Journal of Performance of Constructed Facilities, 17(3), pp. $151-158$ 